\title{
PENERAPAN KEPALA BERNOMOR BERBASIS AKTIVITAS MENGOMUNIKASIKAN UNTUK MENINGKATKAN MOTIVASI BELAJAR PADA SISWA KELAS IIIA SEMESTER I SD LABORATORIUM UNDIKSHA SINGARAJA
}

\author{
Jatien Sri Nandang1*, I Wayan Widiana ${ }^{2 *}$ \\ ${ }^{1}$ Jurusan Pendidikan Guru Sekolah Dasar, Universitas Pendidikan Ganesha, Indonesia \\ ${ }^{2}$ Jurusan Pendidikan Guru Sekolah Dasa , Universitas Pendidikan Ganesha, Indonesia
}

\section{Abstrak}

Tujuan penelitian ini adalah untuk mengetahui peningkatan motivasi belajar setelah penerapan model pembelajaran kooperatif tipe Kepala Bernomor Berbasis Aktivitas Mengomunikasikan pada siswa kelas IIIA semester I SD Laboratorium Undiksha Singaraja, Kec. Buleleng, Kab. Buleleng tahun pelajaran 2017/2018. Penelitian ini adalah penelitian tindakan kelas yang dilaksanakan dalam dua siklus. Subjek penelitian adalah siswa kelas IIIA semester I SD Laboratorium Undiksha Singaraja, Kec. Buleleng, Kab. Buleleng tahun pelajaran 2017/2018, sebanyak 35 orang. Pengumpulan data dalam penelitian ini dilakukan dengan metode kuesioner. Data yang telah didapatkan selanjutnya dianalisis dengan menggunakan metode analisis deskriptif kuantitatif. Data hasil penelitian menunjukkan pada siklus I data hasil motivasi belajar siswa secara klasikal mencapai 78 \% pada kategori tinggi namun masih perlu peningkatan lagi. Pada siklus II secara klasikal mencapai 82 \% pada kategori sangat tinggi dan secara keseluruhan motivasi belajar siswa berada pada kategori tinggi atau sangat tinggi. Dengan demikian peningkatan motivasi belajar siswa mencapai $4 \%$. Hasil penelitian ini menunjukkan bahwa penerapan model pembelajaran kooperatif tipe Kepala Bernomor Berbasis Aktivitas Mengomunikasikan pada siswa kelas IIIA semester I SD Laboratorium Undiksha Kec. Buleleng dapat meningkatkan motivasi belajar siswa kelas IIIA SD Laboratorium Undiksha Singaraja.
\end{abstract}

\section{Keywords:}

kepala bernomor, aktivitas mengomunikasikan, motivasi belajar.

\section{Pendahuluan}

Kurikulum 2013 yang telah diterapkan di jenjang sekolah dasar menjadikan siswa sebagai subyek belajar. Kegiatan pembelajaran dilakukan oleh siswa dan guru menjadi fasilitator. Kurikulum 2013 dengan pendekatan Saintifik memuat kegiatan 5 M dalam sebuah pembelajaran, yaitu mengamati, menanya, menalar, mencoba, dan mengomunikasikan. Siswa menggali informasi, berpikir kritis, melakukan percobaan, dan menemukan konsep dari pembelajaran yang telah dilakukan bersama guru. Siswa dilatih untuk belajar mandiri dalam setiap pembelajaran. Selain dengan pendekatan Saintifik, Kurikulum 2013 juga memuat penanaman dan pembiasaan karakter sikap dalam setiap pembelajaran. Pembelajaran dikemas dalam satu kesatuan, menggabungkan beberapa muatan pelajaran secara terpadu, sehingga siswa belajar secara holistik. Dengan penerapan Kurikulum 2013 diharapkan kegiatan siswa dalam belajar menjadi suatu pengalaman yang akan diingat dalam jangka panjang pada diri siswa. Penerapan Kurikulum 2013 berpusat pada siswa, sehingga faktor dari dalam diri siswa sangat mempengaruhi keberhasilan pembelajaran. Salah satu faktornya adalah motivasi belajar siswa. Motivasi belajar merupakan faktor psikis yang bersifat non-intelektual. Peranannya yang khas adalah dalam hal menumbuhkan hasrat dan keinginan untuk belajar yang lebih bermakna. Motivasi memiliki akar kata dari bahasa latin movere, yang berarti gerak atau dorongan untuk bergerak (Prawira, 2012). Dengan adanya motivasi siswa mampu melakukan pembelajaran yang lebih bermakna, sehingga terjadi perubahan tingkah laku siswa, dari yang tidak tahu menjadi tahu atau tidak bisa menjadi bisa. Perubahan tersebut 
bersifat positif dan meningkatkan kemampuan siswa, baik dalam ranah kognitif, afektif, maupun psikomotor.

Dalam pembelajaran, motivasi belajar merupakan salah satu faktor yang menentukan keberhasilan siswa. Motivasi belajar merupakan kekuatan (power motivation), daya pendorong (driving force) atau alat pembangun kesediaan dan keinginan yang kuat dalam diri siswa untuk belajar secara aktif, kreatif, inovatif, dan menyenangkan dalam rangka perubahan perilaku, baik dalam aspek kognitif, afektif, maupun psikomotor (Hanafiah, 2009). Motivasi belajar merupakan faktor psikis yang bersifat non-intelektual. Peranannya yang khas adalah dalam hal menumbuhkan hasrat dan keinginan untuk belajar yang lebih bermakna. Kegiatan pembelajaran yang telah dipersiapkan guru diharapkan dapat berjalan sesuai dengan rencana dan tujuan yang ingin dicapai. Salah satu tujuan pembelajaran itu adalah terjadinya perubahan tingkah laku yang berupa munculnya motivasi belajar siswa yang optimal. Motivasi belajar dapat mempengaruhi keberhasilan pencapaian belajar, namun motivasi bukanlah satu-satunya hal yang mempengaruhi, melainkan masih ada faktor-faktor lain yang dapat mempengaruhi keberhasilan pembelajaran.

Motivasi merupakan faktor yang sangat penting dalam proses belajar guna mencapai prestasi yang diharapkan. Motivasi merupakan pendorong dan penggerak individu yang dapat menimbulkan dan memberikan arah bagi individu untuk melakukan aktivitasaktivitas tertentu untuk mencapai tujuannya. Standar nilai baik nilai ketuntasan belajar maupun kelulusan yang ditetapkan secara nasional yang harus dicapai oleh siswa dapat meningkatkan motivasi siswa dalam belajar dan berprestasi. Hamalik (2001:161) mengatakan bahwa fungsi motivasi yaitu sebagai berikut. 1) Mendorong timbulnya kelakuan atau suatu perbuatan. Tanpa motivasi maka tidak akan timbul sesuatu perbuatan seperti belajar; 2) Motivasi berfungsi sebagai pengarah. Artinya mengarahkan perbuatan kepencapaian tujuan yang diinginkan; 3) Motivasi berfungsi sebagai penggerak. Ia berfungsi sebagai mesin bagi mobil. Besar kecilnya motivasi akan menentukan cepat atau lambatnya suatu pekerjaan. Motivasi berprestasi adalah rangkaian dorongan yang menggerakkan seseorang untuk melakukan keinginan yang dilandasi adanya tujuan mencapai prestasi yang baik. Berdasarkan hasil pengamatan di kelas ditemukan siswa yang memiliki cara kerja berbeda-beda dalam menyelesaikan tugasnya. Ada yang amat giat untuk mencapai sukses, ada yang sedangsedang saja, bahkan ada pula yang tampaknya tidak ada gairah. Siswa yang mempunyai motivasi berprestasi tinggi cenderung berusaha untuk menyelesaikan tugasnya secara tuntas tanpa menunda-nunda pekerjaannya. Motivasi belajar yang dimiliki siswa dalam setiap kegiatan pembelajaran sangat berperan untuk meningkatkan prestasi belajar siswa dalam mata pelajaran tertentu (Nashar, 2004:11). Siswa yang bermotivasi tinggi dalam belajar memungkinkan akan memperoleh hasil belajar yang tinggi pula, artinya semakin tinggi motivasinya, semakin intensitas usaha dan upaya yang dilakukan, maka semakin tinggi prestasi belajar yang diperolehnya. Biggs dan Tefler (dalam Dimyati dan Mudjiono, 2006) mengungkapkan motivasi belajar siswa dapat menjadi lemah. Lemahnya motivasi atau tiadanya motivasi belajar akan melemahkan kegiatan, sehingga mutu prestasi belajar akan rendah. Oleh karena itu, mutu prestasi belajar pada siswa perlu diperkuat terus-menerus. Dengan tujuan agar siswa memiliki motivasi belajar yang kuat, sehingga prestasi belajar yang diraihnya dapat optimal.

Faktor dari guru atau pendidik juga tidak kalah penting perannya dalam mencapai keberhasilan pembelajaran. Guru yang membuat skenario pembelajaran agar dapat mencapai tujuan yang telah ditetapkan. Cara membelajarkan, penggunaan media dan metode pembelajaran yang dipilih guru merupakan salah satu cara meningkatkan kualitas pembelajaran. Hamalik (2001:2) juga menyatakan bahwa, "untuk lebih mengefektifkan komunikasi dan interaksi antara guru dan siswa dalam proses pendidikan dan pengajaran, di sekolah perlu digunakan metode dan teknik yang tepat". Berdasarkan pendapat tersebut dapat disimpulkan bahwa metode yang tepat dapat menciptakan pembelajaran yang aktif, kreatif, menyenangkan, dan mengefektifkan komunikasi siswa dan guru.

Model pembelajaran kepala bernomor terinspirasi dari model kooperatif tipe Numbered Head Together (NHT) yang dikembangkan oleh Spencer Kagan tahun 1992. Siswa dibentuk dalam kelompok-kelompok kecil yang setiap siswa mempunyai nomor yang berbeda-beda dalam satu kelompok. Siswa diajak untuk berpikir bersama dengan teman kelompoknya. Dalam pelaksanaannya model pembelajaran ini juga merujuk pada interaksi siswa kepada teman satu kelompok maupun siswa pada kelompok lain. Guru menjadi fasilitator dalam pelaksanaan pembelajaran ini.

Ibrahim (dalam Nardi, 2011) mengemukakan tiga tujuan yang hendak dicapai dalam pembelajaran kooperatif dengan tipe Numbered Head Together (NHT) yaitu : (1) Hasil belajar akademik stuktural, (2) Pengakuan adanya keragaman, dan (3) Pengembangan keterampilan sosial. Keterampilan yang dimaksud antara lain berbagi tugas, aktif bertanya, menghargai pendapat orang lain, mau menjelaskan ide atau pendapat, bekerja dalam kelompok dan sebagainya. Penerapan model Kepala Bernomor dalam penelitian ini dilakukan sebagai salah satu kegiatan siswa dalam mengomunikasikan hasil-hasil diskusi yang telah 
dilakukan oleh siswa, bukan secara menyeluruh diterapkan sebagai model pembelajaran dalam satu pembelajaran.

Mengomunikasikan adalah salah satu rangkaian kegiatan 5M dalam pendekatan Saintifik Kurikulum 2013. Mengomunikasikan adalah kegiatan menyampaikan pendapat dan hasil diskusi kepada seluruh siswa maupun guru. Mengomunikasikan menjadi salah satu kegiatan yang cukup menantang untuk siswa. Karena dengan adanya kegiatan mengomunikasikan siswa tersebut mendapat tuntutan dan merasa perlu untuk giat belajar jika sewaktu-waktu ditunjuk sebagai perwakilan kelompok. Seluruh siswa dengan nomor yang berbeda harus bersiap ketika nomor kepalanya dipilih oleh guru. Komunikasi ini tidak hanya memicu siswa untuk belajar aktif dalam kelompoknya, tetapi juga belajar berani menyampaikan atau berbicara di depan kelas.

Berdasarkan observasi selama pengalaman praktik lapangan dan wawancara dengan guru kelas IIIA di SD Laboratorium Undiksha ditemukan bahwa motivasi belajar siswa sebagian rendah. Hal ini disebabkan karena beberapa faktor, 4 dari 35 siswa (11\%) merasa malas dalam belajar, 7 dari 35 (20\%) siswa lebih suka bermain daripada belajar, 14 dari $35(40 \%)$ siswa sering berbicara dengan teman saat belajar, 5 dari 35 (14\%) siswa mengalami kesulitan materi di kelas.

Faktor yang pertama yaitu siswa merasa malas belajar, faktor tersebut datang dari dalam diri siswa yang lebih suka bermain daripada belajar. Yang kedua, siswa kurang tertarik dengan kegiatan belajar, ketika kegiatan pembelajaran siswa kurang memperhatikan buku dan guru, tetapi sembunyi-sembunyi bermain dan bercakap dengan temannya. Faktor ketiga siswa kesulitan memahami materi, siswa sudah mengikuti pembelajaran tetapi merasa kesulitan dalam memahami materi yang disampaikan oleh guru. Sehingga mempengaruhi pada pencapaian keberhasilan pembelajaran setiap hari. Dari permasalahanpermasalahan yang ada, mendorong untuk segera dilakukan perbaikan agar siswa mempunyai motivasi belajar yang tinggi dengan melakukan penelitian tindakan kelas. Untuk meningkatkan motivasi belajar siswa, perlu adanya tindakan penelitian dengan judul "Penerapan Kepala Bernomor Berbasis Aktivitas Mengomunikasikan Untuk Meningkatkan Motivasi Belajar Pada Siswa Kelas IIIA Semester I SD Laboratorium Undiksha Singaraja Tahun Pelajaran 2017/2018". Penelitian ini dilakukan untuk mendeskripsikan penerapan model kepala bernomor berbasis aktivitas mengomunikasikan, aktivitas belajar siswa, kendala, dan solusi dalam meningkatkan motivasi belajar pada siswa kelas IIIA Semester I SD Laboratorium Undiksha Singaraja. Sehingga kelas tersebut dapat melaksanakan proses belajar dengan baik sesuai dengan karakteristik siswanya.

\section{Metode Penelitian}

Jenis penelitian ini adalah penelitian tindakan kelas (classroom action research). Penelitian tindakan kelas adalah penelitian yang dirancang dalam bentuk siklus guna meningkatkan hal-hal yang berkaitan dengan aktivitas siswa yang masih rendah untuk memperbaiki kualitas pembelajaran pada kelas tersebut. Prosedur penelitian ini dirancang dalam bentuk siklus. Tiap siklus terdiri atas empat fase sesuai dengan model yang dikemukakan oleh Kemmis dan Mc Taggart yaitu: perencanaan (planning), tindakan (action), observasi atau evaluasi (observing) dan refleksi (reflecting). Penelitian ini telah dilakukan pada siswa kelas IIIA Semester I di SD Laboratorium Undiksha Singaraja, Kecamatan Buleleng, Kabupaten Buleleng, Provinsi Bali, dengan jumlah siswanya sebanyak 35 orang dengan rincian 23orang siswa laki-laki dan 12 orang siswa perempuan. Penelitian ini dilaksanakan selama empat bulan pada Semester I.

Untuk mengumpulkan data dalam penelitian ini digunakan metode tes kinerja. Instrumen yang digunakan untuk mengukur motivasi belajar siswa berupa kuesioner motivasi belajar. Rubrik ini untuk mendemonstrasikan atau mengaplikasikan motivasi belajar yang telah dimiliki siswa dan menggambarkan motivasi belajar siswa melalui suatu proses kegiatan atau unjuk kerja (Majid, 2006:88). Setelah data dalam penelitian ini terkumpul maka selanjutnya dilakukan analisis data. Dalam menganalisis data ini digunakan metode analisis deskriptif kuantitatif. Untuk memperoleh motivasi belajar siswa secara klasikal, menggunakan rumus sebagai berikut.

Rumus analisis data hasil observasi :

$\mathrm{M}=$ (jumlah skor setiap siswa)/(jumlah indikator)

Keterangan :

M = Motivasi siswa dari hasil observasi (Sudjana, 2015:13).

Untuk melihat motivasi siswa dalam kegiatan proses belajar dilakukan analisis skoring dengan asumsi sebagai berikut.

Interval masing-masing kelas : $\mathrm{x}=(\mathrm{a}-\mathrm{b}) / \mathrm{n}$

Keterangan :

$\mathrm{x}=$ interval kelas 
a = jumlah skor tertinggi

b = jumlah skor terendah

$\mathrm{n}$ = banyaknya kelas

dari rumus perhitungan tersebut, didapatkan interval kelasnya adalah sebagai berikut.

$\mathrm{i}=(\mathrm{a}-\mathrm{b}) / \mathrm{n}$

$\mathrm{i}=(200-40) / 4$

$\mathrm{i}=160 / 4$

$\mathrm{i}=40$

Selanjutnya untuk menganalisis tinggi rendahnya motivasi belajar siswa dikonversikan ke dalam Penilaian Acuan Patokan (PAP) skala empat. Dengan rincian sebagai berikut.

\section{Hasil Dan Pembahasan}

Kegiatan penelitian dilaksanakan pada bulan Juli-Oktober 2017 pada siswa kelas IIIA SD Laboratorium Undiksha Tahun Pelajaran 2017/2018 dengan jumlah siswa 35 orang terdiri dari 23 orang siswa laki-laki dan 12 orang siswa perempuan. Pra siklus telah dilaksanakan tes kuesioner untuk mengetahui motivasi awal siswa sebelum dilakukan tindakan. Rata-rata klasikal motivasi siswa kelas IIIA Pra siklus mencapai skor 136 (68\%), berada pada kategori motivasi tinggi. Namun secara individu masih ada siswa yang berada di kategori motivasi sedang.

Pada siklus I dilaksanakan dua pertemuan dengan model pembelajaran kooperatif tipe Kepala Bernomor berbasis aktivitas mengomunikasikan. Siswa dibagi menjadi 6 kelompok, setiap kelompok terdiri dari 5-6 orang siswa. Siklus I dimulai dengan membuat perencanaan, melaksanakan pembelajaran, melakukan observasi, dan melakukan refleksi untuk mengetahui kekurangan pada siklus I sebagai bahan untuk melanjutkan perencanaan di siklus II. Dalam membuat perencanaan yang pelu disiapkan adalah RPP, lembar observasi, menyiapkan kuesioner motivasi belajar, LKS siswa, lembar evaluasi, serta media yang diperlukan selama pembelajaran. Yang kedua melaksanakan pembelajaran sesuai dengan RPP yang telah dirancang sambil melakukan observasi aktivitas siswa saat pembelajaran berlangsung. Hal itu dilakukan selama dua pertemuan. Setelah dilakukan observasi diperoleh hasil analisis observasi motivasi belajar siswa siklus I, diperoleh data siswa yang memiliki motivasi tingkat sedang sudah tidak ada, siswa yang memiliki motivasi tingkat tinggi sebanyak 22 dari 35 (63\%) siswa, dan siswa yang memiliki motivasi tingkat sangat tinggi meningkat menjadi 13 dari 35 (37\%) siswa. Untuk menghitung rata-rata kelas digunakan rumus sebagai berikut.

$$
\begin{aligned}
\text { Rata-rata }(\mathrm{RN}) & =\left(\sum \mathrm{X}\right) / \mathrm{N} \\
\mathrm{RN} & =5432 / 35 \\
\mathrm{RN} & =155
\end{aligned}
$$

Berdasarkan analisis di atas maka skor rata-rata motivasi belajar siswa secara klasikal mencapai 155 dengan skor perolehan 5432. Perolehan nilai rata-rata klasikal motivasi belajar siswa pra siklus adalah 136 (68\%) dan setelah diterapkan tindakan pada siklus I skornya meningkat $19(9,5 \%)$ menjadi 155 (78\%). Sehingga Apabila dikonversikan ke dalam PAP skala empat untuk kriteria motivasi belajar secara klasikal maka motivasi belajar untuk siklus I tergolong tinggi.

Berdasarkan hasil refleksi pada siklus I terdapat kekurangan yang harus diperbaiki pada siklus selanjutnya., Pembelajaran pada siklus II perlu dilakukan perbaikan, maka tindakan perbaikan yang akan diberikan adalah dengan menambah inovasi dalam pembelajaran yaitu dengan menambah dan memberikan kuis, menampilkan video dengan animasi yang lebih menarik, memberikan penghargaan yang lebih dan berimbang bagi kelompok yang mampu, dan menerapkan hukuman verbal agar lebih tertib dalam pembelajaran. Sehingga diharapkan siswa dapat lebih menumbuhkan motivasi siswa untuk belajar dan diharapkan prestasi siswa dapat meningkat. Dengan tindakan perbaikan tersebut, diharapkan motivasi belajar siswa bisa lebih meningkat pada siklus II yang akan dilaksanakan.

Siklus II dilaksanakan dua pertemuan dengan model pembelajaran kepala bernomor berbasis aktivitas mengomunikasikan. Siswa dikelompokkan menjadi 6 kelompok, setiap kelompok terdiri dari 5-6 orang. Siklus II dimulai dengan membuat perencanaan, melaksanakan pembelajaran, melakukan observasi, dan melakukan perbaikan berdasarkan hasil refleksi pada siklus I. Dalam membuat perencanaan yang pelu disiapkan adalah RPP, lembar observasi, menyiapkan kuesioner motivasi belajar, LKS siswa, lembar evaluasi, serta media yang diperlukan selama pembelajaran. Dalam melaksanakan pembelajaran sesuai dengan RPP yang telah dirancang. Selanjutnya melakukan observasi aktivitas siswa saat pembelajaran berlangsung. Hal itu dilakukan selama dua pertemuan.

Pada pelaksanaan siklus II setiap pembelajaran peneliti memberikan reward kepada setiap kelompok yang mampu mengerjakan LKS dengan tertib, disiplin, dan sesuai dengan petunjuk. Sejalan dengan hal tersebut juga berlaku hukuman verbal untuk kelompok yang tidak tertib dan tidak mengikuti 
petunjuk dalam mengerjakan LKS. Pembelajaran menjadi lebih tertib dan menyenangkan. Siswa berprtisipari aktif pada saat pembelajaran.

Inovasi lain yang ditambahkan saat melaksanakan pembelajaran di siklus II yaitu dengan memberikan kuis. Kuis diberikan kepada seluruh kelompok dengan pertanyaan teka-teki tentang materi yang sudah dipelajari ataupun ditayangkan pada video yang telah diamati oleh siswa. Siswa dengan antusias menjawab setiap pertanyaan. Namun dengan kuis tersebut guru juga memilih nomor kepala yang akan menjawab di kelompok tersebut. Sehingga terjadilah proses diskusi yang melibatkan seluruh anggota kelompok agar semua siswa dapat berpartisipasi aktif dalam belajar.

Pertemuan terakhir pada siklus II siswa mengisi kuesioner tentang motivasi belajar. Pada siklus II data hasil tes kuesioner siklus II dapat dinyatakan bahwa terjadi peningkatan motivasi belajar siswa. Hal tersebut didukung berdasarkan kuantitas siswa yang mengalami peningkatan, siswa yang memiliki motivasi tingkat sedang sudah tidak ada, siswa yang memiliki motivasi tingkat tinggi sebanyak 11 dari 35 (31\%) siswa, dan siswa yang memiliki motivasi tingkat sangat tinggi meningkat menjadi 24 dari 35 (69\%) siswa. Untuk menghitung rata-rata kelas digunakan rumus sebagai berikut.

$$
\begin{aligned}
\text { Rata-rata }(\mathrm{RN}) & =\left(\sum \mathrm{X}\right) / \mathrm{N} \\
\mathrm{RN} & =5735 / 35 \\
\mathrm{RN} & =164
\end{aligned}
$$

Berdasarkan analisis di atas maka skor rata-rata motivasi belajar siswa secara klasikal mencapai 164 (82\%) dengan skor perolehan 5735. Berikut disajikan tabel perbandingan hasil perolehan nilai motivasi belajar siswa pada siklus I dan siklus II.

\begin{tabular}{|c|c|c|c|c|c|c|c|c|}
\hline Aspek & \multicolumn{2}{|c|}{$\begin{array}{c}\text { Sangat Tinggi } \\
(160-200)\end{array}$} & \multicolumn{2}{|c|}{$\begin{array}{c}\text { Tinggi } \\
(120-159)\end{array}$} & \multicolumn{2}{|c|}{$\begin{array}{c}\text { Sedang } \\
(80-119)\end{array}$} & \multicolumn{2}{|c|}{$\begin{array}{c}\text { Rendah } \\
(40-79)\end{array}$} \\
\hline & siklus & siklus & siklus & siklus & siklus & siklus & siklus & siklus \\
\hline & I & II & I & II & I & II & I & II \\
\hline Motivasi & 13 & 24 & 22 & 11 & 0 & 0 & 0 & 0 \\
\hline & 37 & 69 & 63 & 31 & 0 & 0 & 0 & 0 \\
\hline
\end{tabular}

Tabel 2. Perbandingan Hasil Perolehan Nilai Motivasi Belajar Siswa pada Siklus I dan II Perolehan Nilai Siswa

Berdasarkan Tabel 2, telah terjadi peningkatan motivasi belajar pada siswa dari siklus I ke siklus II. Siswa yang mempunyai motivasi tinggi pada siklus I sebanyak 22 siswa (63\%) dan pada siklus II menjadi 11 siswa (31\%). Kemudian siswa yang mempunyai motivasi sangat tinggi pada siklus I sebanyak 13 siswa (37\%) meningkat menjadi 24 siswa (69\%). Hal tersebut didukung berdasarkan jumlah siswa yang mengalami peningkatan motivasi belajar. Sebanyak 35 orang siswa setelah dilakukan tes kuesioner siklus II nilai motivasi belajar yang diperoleh meningkat secara signifikan. Implementasi pendekatan Saintifik dengan model pembelajaran kepala bernomor berbasis aktivitas mengomunikasikan dalam pembelajaran tematik dapat meningkatkan motivasi belajar pada siswa Kelas III A SD Lab Undiksha. Untuk lebih jelasnya, data perbandingan perolehan nilai motivasi belajar siswa selama 2 siklus dapat digambarkan dalam bentuk gambar di bawah ini. 


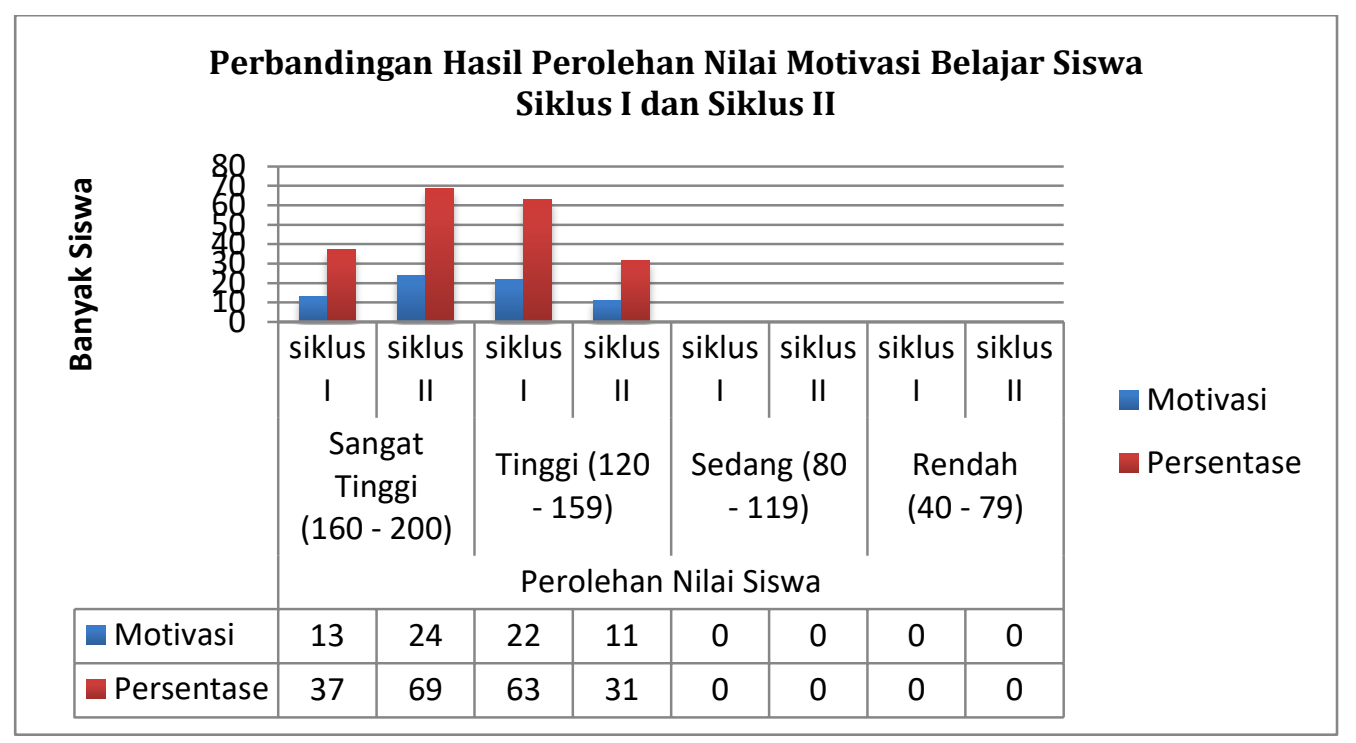

Penelitan ni dilaksanakan di SD Laboratorium Undiksha Singaraja pada siswa kelas IIIA semester I tahun pelajaran 2017/2018, banyak siswa kelas IIIA adalah 35 siswa yang terdiri dari dari 23 orang siswa laki-laki dan 12 orang siswa perempuan. Pada penelitian ini yang diukur adalah motivasi belajar melalui penerapan model pembelajaran kooperatif tipe Kepala Bernomor Berbasis Aktivitas Mengomunikasikan. Penelitian ini dirancang melalui beberapa siklus hingga menemukan tindakan yang terbaik. Pada siklus I terdiri dari perencanaan, pelaksanaan, observasi atau evaluasi dan refleksi. Hasil refleksi pada siklus I akan digunakan sebagai bahan perbaikan di siklus selanjutnya.

Apabila siklus I belum berhasil akan dilanjutkan ke siklus II yang terdiri perencanaan, pelaksanaan, observasi atau evaluasi dan refleksi siklus II, apabila berhasil maka penelitian akan dihentikan karena telah mencapai target yang ditentukan, dan apabila belum mencapai target yang ditentukan maka dilanjutkan ke siklus berikutnya. Pra siklus telah dilaksanakan tes kuesioner untuk mengetahui motivasi siswa seblum penerapan model pembelajaran kepala bernomor berbasis aktivitas mengomunikasikan. Hasil penelitian menunjukkan motivasi belajar pada siklus I sudah mencapai kriteria keberhasilan, namun masih perlu adanya peningkatan secara individual. Walaupun secara klasikal rata-rata motivasi belajar seluruh siswa sudah pada kategori tinggi dan ada yang sudah sangat tinggi. Dalam hal ini masih perlu perlu perbaikan karena ada beberapa siswa yang kurang memperhatikan guru ketika proses pembelajaran berlangsung, siswa asik menggambar saat temannya berdiskusi, dan siswa yang aktif berusaha mendominasi kelompok dan kelas, sehingga motivasi belajar siswa belum mencapai kriteria keberhasilan yang ditentukan dalam penelitian ini. Maka dari itu segala upaya dan inovasi dirancang untuk menanggulangi kelemahan pada siklus I dan selanjutnya akan dilaksanakan pada siklus II. Pada siklus II ini segala yang dirancang dan diupayakan berjalan dengan lancar sehingga pada siklus II ini terjadi peningkatan motivasi belajar.

Berdasarkan analisis rata-rata klasikal motivasi belajar siswa pada pra siklus adalah $68 \%$. Terjadi peningkatan aktivitas motivasi belajar siswa sebanyak 9,5\% menjadi 78\%. Sedangkan pada siklus I ke Siklus II terjadi peningkatan 4\% menjadi 82\%. Siklus I motivasi belajar mencapai nilai 155 (68\%) pada kategori motivasi tinggi. Sedangkan pada siklus II mencapai nilai 164 (82\%) pada kategori motivasi sangat tinggi, selain itu seluruh siswa sudah berada pada kategori motivasi belajar tinggi atau sangat tinggi. Sehingga terjadi peningkatan 14\% motivasi belajar siswa secara klasikal setelah diterapkan model pembelajaran Kepala Bernomor berbasis mengomunikasikan. Hal ini menunjukkan terjadi peningkatan dari siklus I ke siklus II dan terjadi peningkatan motivasi belajar secara individu maupun secara rata-rata klasikal secara keseluruhan. Secara umum penelitian ini dapat dikatakan berhasil, karena mampu meningkatkan motivasi belajar siswa kelas IIIA SD Laboratorium Undiksha Singaraja.

\section{Simpulan dan Saran}

Berdasarkan hasil penelitian dan pembahasan yang telah diuraikan, dapat disimpulkan bahwa penerapan model pembelajaran kooperatif tipe Kepala Bernomor berbasis aktivitas mengomunikasikan dapat meningkatkan motivasi belajar siswa di kelas IIIA semester I SD Laboratorium Undiksha tahun pelajaran 2017/2018. Hal ini dapat dilihat dari meningkatnya motivasi belajar siswa pada siklus I yang mencapai skor 155 pada kategori motivasi tinggi. Sedangkan pada siklus II mencapai skor 164 pada 
kategori motivasi sangat tinggi, selain itu seluruh siswa sudah berada pada kategori motivasi belajar tinggi atau sangat tinggi. Hal ini menunjukkan terjadi peningkatan sebesar 4,6 \% dari siklus I ke siklus II dan terjadi peningkatan motivasi belajar secara individu maupun secara rata-rata klasikal secara keseluruhan.

Sehubungan dengan hasil yang telah dicapai dalam penelitian ini, ada beberapa saran yang dapat sampaikan. Diharapkan kepada seluruh siswa khususnya di SD Laboratorium Undiksha Singaraja untuk memanfaatkan pengalaman belajar yang didapat setelah diterapkan model pembelajaran kooperatif tipe Kepala Bernomor berbasis aktivitas mengomunikasikan dalam pembelajaran tematik sehingga motivasi belajar siswa dapat terus meningkat sejalan dengan hasil belajar yang terus meningkat.

Sesuai dengan hasil penelitian tindakan kelas ini, disarankan kepada guru (pengajar) agar dapat mempertimbangkan penerapan model pembelajaran kooperatif tipe Kepala Bernomor berbasis aktivitas mengomunikasikan ini sebagai salah satu alternatif pilihan model pembelajaran dalam pembelajaran tematik pada aktivitas mengomunikasikan guna meningkatkan motivasi belajar dan hasil belajar yang dicapai siswa. Selanjutnya, kepada Kepala SD Laboratorium Undiksha Singaraja diharapkan agar hasil penelitian ini dapat dijadikan referensi untuk membimbing dan mengarahkan staf pengajarnya dalam mengelola kegiatan pembelajaran sehingga pelaksanaan kegiatan pembelajaran menjadi lebih efektif.

Bagi para peneliti lain yang akan mengadakan penelitian lebih lanjut dan sejenis tentang penerapan model pembelajaran kooperatif tipe Kepala Bernomor berbasis aktivitas mengomunikasikan hendaknya lebih memperhatikan kendala-kendala yang dihadapi siswa dalam pembelajaran serta mengupayakan solusi pemecahan yang tepat agar penelitian yang dilaksanakan dapat mencapai motivasi belajar yang lebih optimal sehingga dapat lebih memperkaya strategi pembelajaran namun tetap dapat memuat kegiatan 5M dalam Kurikulum 2013.

\section{Daftar Pustaka}

Agung, A. A. Gede. 2014. Metodologi Penelitian Pendidikan. Singaraja: FIP Undiksha.

Arikunto, Suharsimi. 2007. Prosedur Penelitian Suatu Pendekatan Praktek. Jakarta: Rineka Cipta.

Brophy, Jere. 2004. Motivating Students to Learning. New Jersey: Lawrence Erlbaum Associates.

Darmadi, Hamid. 2011. Metode Penelitian Pendidikan. Bandung: Alfabeta.

Dimyati dan Moedjono. 1994. Strategi Belajar Mengajar. Jakarta: P2TK Ditjen DIKTI Depdikbud.

Dimyati dan Mudjiono. (2006). Belajar dan Pembelajran. Jakarta: PT Rajagrafindo Persada.

Direktorat Pembinaan Sekolah Dasar. 2016. Panduan TeknisPembelajaran dan Penilaian di Sekolah Dasar. Jakarta: Kementerian Pendidikan dan Kebudayaan Direktorat Jenderal Pendidikan Dasar dan Menengah Direktorat Pembinaan Sekolah Dasar.

Ekawarna. 2009. Penelitian Tindakan Kelas. Jakarta: Gaung Persada.

Gading, I Kt. 2007. "Penerapan Pembelajaran Kooperatif untuk Meningkatkan Konsep Diri dan Prestasi Belajar dalam Mata Kuliah Perkembangan Belajar Peserta Didik". Laporan Penelitian. Singaraja: Universitas Pendidikan Ganesha.

Hamalik, Oemar. 2003. Belajar dan Pembelajaran. Jakarta: Rineka Cipta.

Hamalik, Oemar 2001. Proses Belajar Mengajar. Bandung: Bumi aksara.

Hamidi. 2004. Evaluasi Pendidikan. Jakarta: Bumi Aksara.

Hanafiah,dan Suhana. 2009. Konsep Strategi Pembelajaran. Bandung: Refika Aditama.

Ibrahim, Muhsin. 2000. Pembelajaran Kooperatif. Surabaya: Univesrsity Press.

Kemis, W.C., \& Taggart, R. M. 1998. The Action Research Planner. Geelong Victoria: Deakin University. 
Khikmawati, Ena. 2012. Peningkatan motivasi belajar siswa yang Berprestasi Rendah Melalui Metode Drill Pada Mata Pelajaran Pendidikan Agama Islam Kelas II SD Negeri Butuh Kec. Tengaran, kab. Semarang Tahun 2012. Skripsi. Salatiga: STAIN Salatiga.

Kurnianto, P. dkk. 2010. Pengembangan Kemampuan Menyimpulkan dan Mengkomunikasikan Konsep Fisika Melalui Kegiatan Praktikum Fisika Sederhana. Jurnal Pendidikan Fisika Indonesia 6. Universitas Negeri Semarang. http://journal.unnes.ac.id. Diakses tanggal 12 September 2017.

Nashar. (2004). Peranan Motivasi dan Kemampuan Awal dalam Kegiatan Pembelajaran. Jakarta: Delia Press.

Prawira, Purwa Atmaja. 2012. Psikologi Pendidikan dalam Perspektif Baru. Malang: Ar-Ruzz Media.

Riduwan. 2008. Metode dan Teknik Menyusun Tesis. Bandung Alfabeta.

Santrock, J.W. 2007. Psikologi Pendidikan Terjemahan. Jakarta: Prenada Media Group.

Sardiman, A. M. 2011. Interaksi \& Motivasi Belajar Mengajar. Jakarta: PT. Raja Grafindo Persada.

Setiawan, Made Putra. 2013. Model Numbered Head Together Berbantuan CD Pembelajaran untuk Meningkatkan Kualitas Pembelajaran IPS Pada Siswa Kelas IVB SDN Purwoyoso 03 Semarang. Skripsi. Universitas Negeri Semarang.

Shoimin, Aris. 2014. 68 Model Pembelajaran Inovatif dalam Kurikulum 2013. Yogyakarta: Ar-ruzz Media.

Slameto. 2003. Belajar dan Faktor-faktor yang Mempengaruhinya. Jakarta: PT Rineka Cipta.

Susanto, Ahmad. 2013. Teori Belajar \& Pembelajaran di Sekolah Dasar. Jakarta: PT Kharisma Putra Utama.

Trisnayanti, Ni Wayan Ririn. 2017. Efektifitas Implementasi Aktivitas Mengkomunikasikan Berbasis Kepala Bernomor dalam Meningkatkan Dimensi Proses Kognitif. International Journal of Elementary Education. http://e-jornal.undiksha.ac.id. Diakses pada tanggal 8 September 2017.

Uno, Hamzah B. dan Nurdin Mohamad. 2011. Belajar dengan Pendekatan PAILKEM. Jakarta: Bumi Aksara. 